Gut, 1969, 10, 255-263

\title{
Skin lesions in ulcerative colitis
}

\author{
M. L. JOHNSON AND H. T. H. WILSON
}

From Central Middlesex Hospital, London

This paper is a study of the skin complications of ulcerative colitis. Between the years 1949 and 1965,415 patients, 230 women and 185 men, were admitted to the Central Middlesex Hospital suffering from this disease. Our object has been to determine the incidence and pattern of the skin disorders in this group and to try to discover if there is any relationship between the skin disease and the severity and extent of the colitis. Twenty patients had dermatoses associated with the bowel disorder and 12 were examined by one of us (H.T.H.W.). The morphological classification is based on these personally observed cases. The sex incidence showed that whereas $55 \%$ of the whole series of colitics were women, $14(70 \%)$ of those who had skin complications were women. Seven developed different types of lesion at different stages of the disease. The main conditions found were erythema nodosum (eight cases), pyoderma gangrenosum (seven cases), papulo-necrotic lesions (five cases), and ulcerating erythematous plaques on the shins (three cases).

\section{ERYTHEMA NODOSUM}

Tender red nodes, generally appearing on the shins and associated with exacerbations of the colitis, occurred in eight patients, all women.

The age of onset of erythema nodosum varied from 21 to 52 years (mean 29 years) and the skin lesions developed at any time from the onset of the first attack of colitis to 16 years later (mean 5.5 years). Although the attacks of erythema nodosum coincided with exacerbations of the colitis there was no correlation with the extent of the disease. Three patients had the entire colon involved; in four the $x$-ray changes were in the left hemicolon and in one case only sigmoidoscopic evidence was present. Six patients had other cutaneous complications of ulcerative colitis and in seven cases there was an associated arthritis, seronegative in all five in whom this investigation was carried out. Four patients eventually had a proctocolectomy whilst the remainder responded to drug therapy. Once the colitis was controlled attacks of erythema nodosum ceased to occur.
In one case several of the erythematous nodes ulcerated.

CASE 1 A housewife had her first attack of bloody diarrhoea at the age of 26 . The attacks became more frequent and the remissions shorter. When she was 30 she had joint pains, especially of the ankles, and six months later a severe relapse of the colitis was associated with erythematous nodules on the shins which broke down to become necrotic ulcers (Fig. 2).

Sigmoidoscopy showed acute colitis and there was a loss of haustration and marked contraction of the descending and sigmoid colon on radiography. There was no response to corticosteroids but a total proctocolectomy six months later was followed by a dramatic improvement in the skin lesions which healed within a month.

\section{PYODERMA GANGRENOSUM}

Seven patients (cases $3,4,10,11,12,13,14$ ) developed chronic ulcers with undermined edges which appeared rapidly and persisted for several weeks. There was little in the way of any local inflammatory reaction and cultures were initially sterile. The lesions appeared on the cheek (case 3), thigh (case 4), foot (case 10), hand (case 13), bilaterally in the inguinal region (case 12), and on the legs (cases $11,13,14)$. The ulcers were up to $1 \frac{1}{2}$ in. $(3.75 \mathrm{~cm})$ in diameter and first appeared as a necrosing inflammatory area (case 4), a spontaneous haematoma which broke down (case 13), or a fluctuant sterile abscess which ulcerated (case 10). In the remainder there was no record as to how the ulcers originated. In no case did the onset of the ulceration coincide with exacerbations of the colitis and there was no parallel between the degree of colonic involvement and the severity of the ulcers. In one case (no. 4) the lesion appeared two and a half years after proctocolectomy. Cases 3 and 10 develloped scattered sterile necrotic papulopustules at the same time as the larger ulcers.

CASE 10 D.W. A housewife first developed diarrhoea with blood and mucus at the age of 21 and had recurrent attacks with long remissions of up to nine years for the following 22 years. At this time she was recovering from 
an exacerbation of colitis and was admitted to hospital for investigation of pain in the neck for which no cause was found. Sigmoidoscopy and barium enema showed the appearances of ulcerative colitis distal to the hepatic flexure.

While in hospital she developed pustules on the face, sternum, and ankles together with a fluctuant abscess which became a necrotic ulcer on the sole of the left foot (Fig. 6). Cultures from all these and from the blood were sterile, but she was febrile and her haemoglobin fell steadily. She was given blood transfusions and tetracycline and the lesions healed in a month. Afterwards she had no more skin lesions but an ischiorectal abscess required surgical drainage the following year.

She continued to have intermittent diarrhoea until she was 46 when her husband was admitted to a mental hospital, since when her bowels have been normal. At 47 she had a hysterectomy and radiotherapy for carcinoma of the uterus. Sigmoidoscopy at the age of 50 (1965) showed a normal rectal mucosa to $20 \mathrm{~cm}$.

CASE 4 E.B. A housewife developed acute ulcerative colitis involving the whole colon and confirmed by simoidoscopy and a barium enema at the age of 21 . Six weeks later she had transient acute arthritis of the right ankle and erythema nodosum on the shins. The colitis responded to antibiotics and supportive therapy, but after remaining well with no skin lesions for two and a half years, she had an emergency total colectomy for impending perforation. A year later the rectal stump was excised. Two and a half years later an indolent necrotic ulcer, $2.5 \mathrm{~cm}$ in diameter, appeared on the right thigh. Biopsy suggested an active pyogenic granulomatous process. The Wassermann reaction was negative. The ulcer healed in six months and she has had no further skin disease.

\section{PAPULONECROTIC LESIONS}

Five patients (cases 2, 3, 10, 13, 15) developed in the course of the disease scattered small erythematous papules which suppurated and then necrosed to form small ulcers which persisted for several weeks. In appearance and behaviour this lesion resembled a papulonecrotic tuberculide. Cultures were sterile in cases 3,10 , and 13 . No culture was taken from case 2 and a Staphylococcus pyogenes was isolated from case 15 . This patient had necrotic pustular lesions on the back, pubis, thighs, and scalp which coincided with exacerbations of the colitis. The condition persisted for a year but cleared after proctocolectomy. The other cases all had other cutaneous manifestations of ulcerative colitis.

Case 2 developed ulcerative colitis at the age of 36 and for five years from the age of 52 crops of erythema nodosum in attacks coinciding with exacerbations of the bowel symptoms. At 57 chronic pustules appeared on the scalp, neck, and trunk once again associated with a relapse of the colitis. These healed slowly leaving small pigmented scars.

Case 10 developed papulopustules on the face, sternum, and ankles while the colitis was in remission and at the same time a fluctuant sterile abscess on the sole of the foot which broke down to form an indolent ulcer.

Case 3, shortly after an attack of erythema nodosum, produced sterile papulopustules on the legs and ankles together with a chronic ulcer on the cheek.

Case 13 had papulopustules around the ears and on the chest. No histology was available from any of these lesions.

Four of the five were women but there was no correlation with the severity of the colitis or the degree of colonic involvement.

\section{ULCERATING ERYTHEMATOUS PLAQUES}

Three patients developed a skin lesion which we have only seen associated with ulcerative colitis or Crohn's disease and which we believe may be a specific skin manifestation of this disease. Initially one or two erythematous plaques up to 3 in. $(7 \cdot 5 \mathrm{~cm})$ in diameter appeared on the shins. These were not raised. The lesions broke down in several places to produce multiple small ulcers which did not coalesce. Resolution took several weeks. There was no particular correlation with the activity of the underlying colitis. Thus case 3 developed the lesions during a relapse of the bowel symptoms; case 5 when the bowels were normal; and case 9 18 months after proctocolectomy. A biopsy from case 5 showed a chronic inflammation with hyalinization of some small vessel walls, but there was no vascular abnormality in case 9 .

CASE 5 Y.D. A housewife had her first attack of ulcerative colitis at the age of 22 confirmed by sigmoidoscopy and a barium enema which showed involvement of the distal half of the colon. She was extremely ill and developed arthritis of the right knee. She responded to antibiotics and parenteral fluids and remained fairly well for a year when a relapse was treated with antibiotics and cortisone $300 \mathrm{mg}$ daily. The bowel symptoms settled but a pustular acne of the face appeared and persisted when the cortisone was stopped. She also developed ecthymatous ulcers on her thighs and buttocks; these were sterile on culture and healed slowly. Nine months later, at $24 \frac{1}{2}$ years of age, the colitis relapsed and after a month there appeared on the front of the legs painful nodular inflammatory lesions resembling erythema nodosum. The colitis settled once more but a month later erythematous plaques appeared on the shins and ulcerated in several places (Fig. 5). Biopsy showed acute abscess formation in the deeper corium with a chronic surround- 


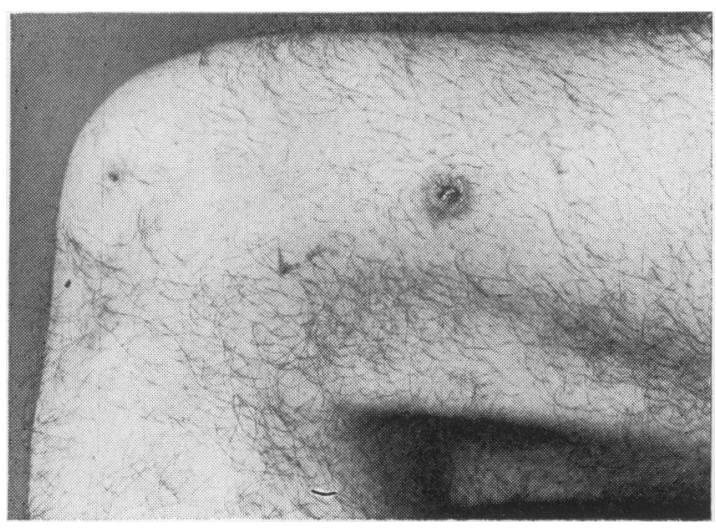

FIG. 1.

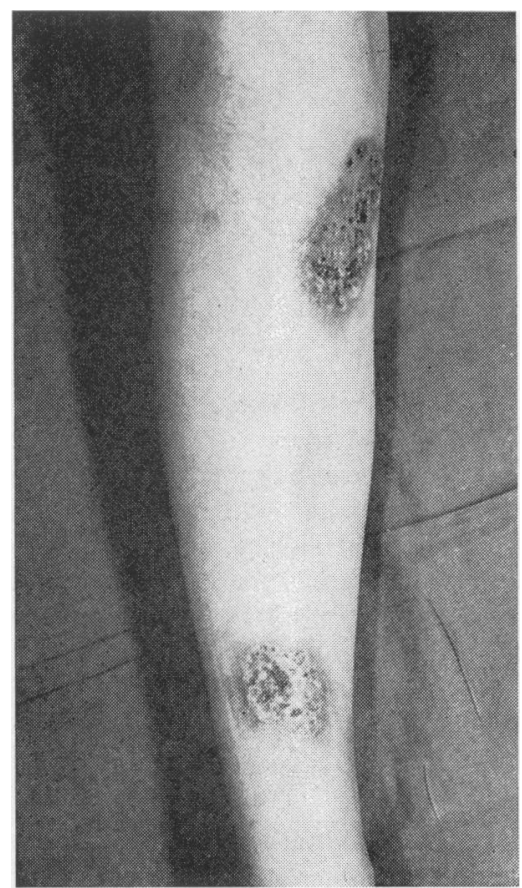

FIG. 3.

FIG. 1. Case 15: chronic ulcerated nodule resembling a papulonecrotic tuberculide on the thigh.

FIG. 2. Case 1: 'erythema nodosum', some lesions showing ulceration.

FIG. 3. Case 3: erythematous plaques on shins with multiple small ulcers.

FIG. 4. Case 9: multiple ulcers on an erythematous plaque on the shin occurring 18 months after proctocolectomy.

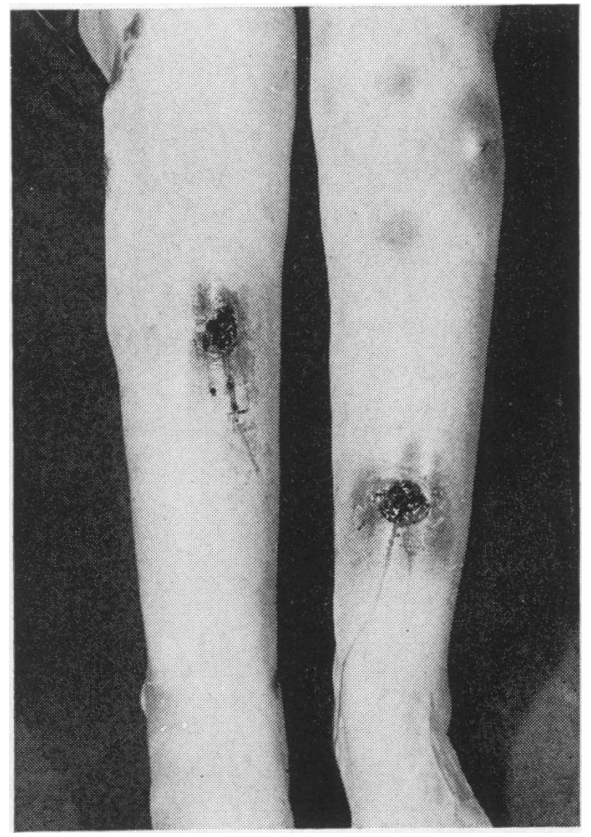

FIG. 2.

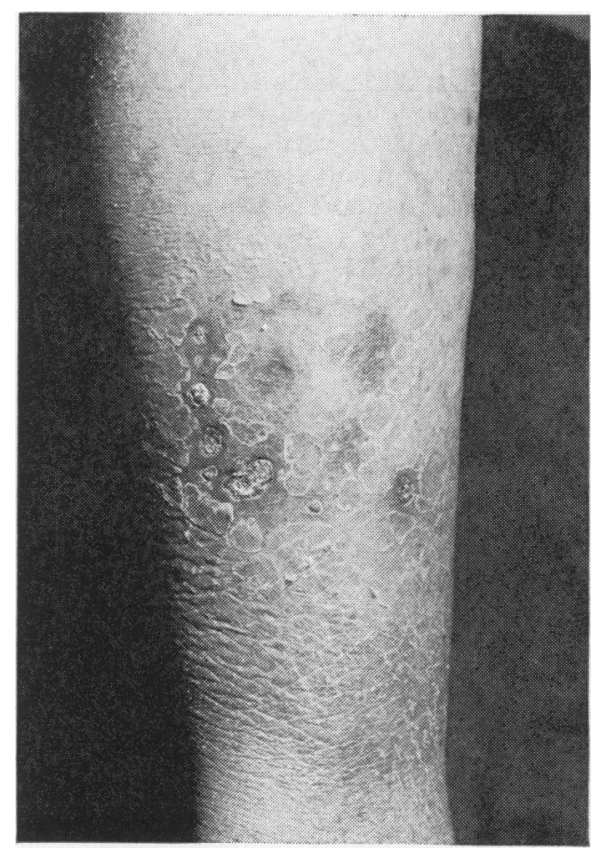

FIG. 4 . 


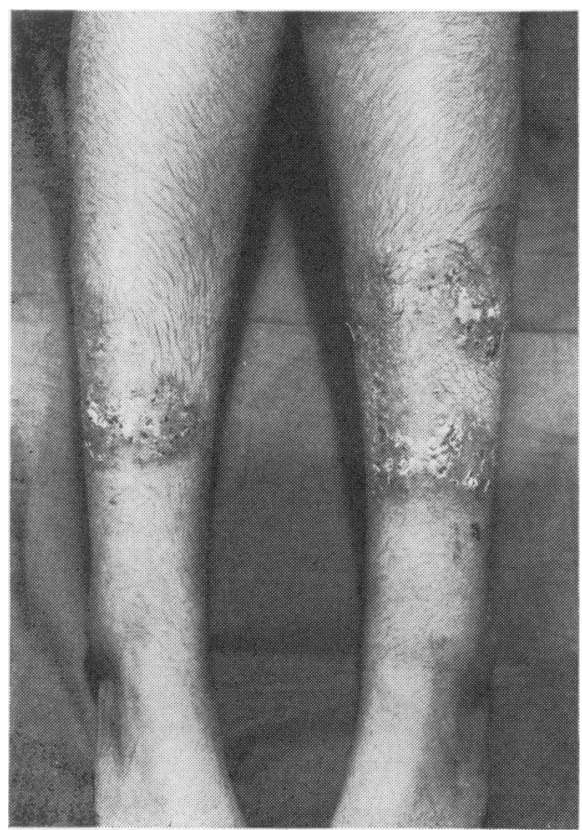

FIG. 5 .

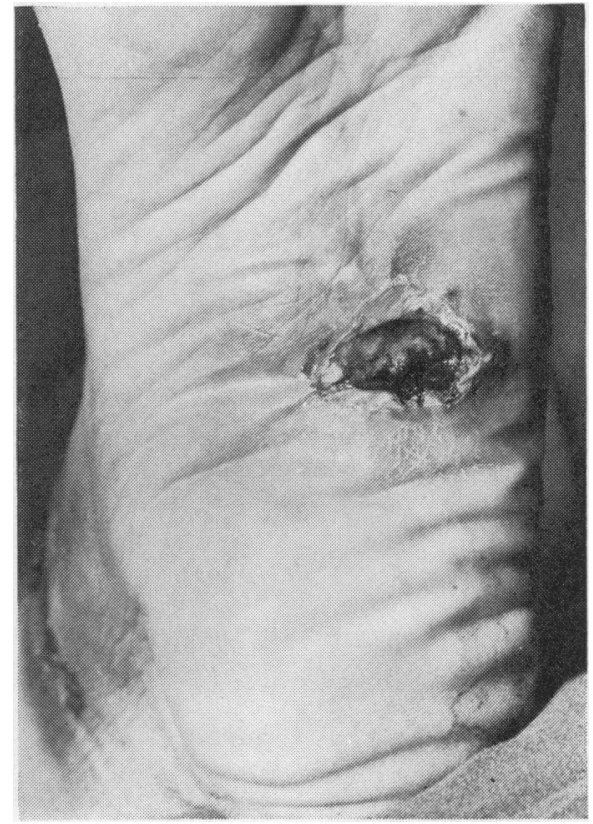

FIG. 6 .
FIG. 5. Case 5: multiple ulcers on erythematous plaques on the shins.

FIG. 6. Case 10: chronic ulcer with undermined edge on the sole of the left foot, 'pyoderma gangrenosum'. ing inflammatory reaction. Some small vessels in the corium showed obliterative changes with hyalinization of their walls. The ulcers did not respond to cortisone, antibiotics, or bed rest but healed gradually over three months. She became pregnant the following year and passed through pregnancy and a normal delivery without any further deterioration but the colitis relapsed three months postpartum and new lesions appeared on the legs. She had a total colectomy and ileorectal anastomosis (Mr S. Aylett) at the age of 26 and has remained well since.

CASE 9 M.K. A housewife had a laparotomy and resection of the pelvic colon for diverticulitis and a paracolic abscess at the age of 64. A year later she began passing blood per rectum. Sigmoidoscopy showed the appearance of acute ulcerative colitis but a barium enema showed no disease in the rest of the colon. However, there was no response to corticosteroids and a total colectomy and ileostomy was performed because early peritonitis had developed. The colon showed the changes of ulcerative colitis with perforation. The rectal stump was excised 18 months later. She made a good recovery but 18 months later developed groups of punched-out, necrotic ulcers on the lateral surface of the right lower leg (Fig. 4). These were initially sterile. A biopsy showed non-specific granulomatous changes with no significant vascular abnormality. The ulcers healed in eight months and there has been no further trouble from bowel or skin.

\section{ERYTHEMA MULTIFORME}

Two patients developed severe erythema multiforme but case 13 was pregnant with pre-eclamptic toxaemia at the time and subsequently aborted a macerated foetus, and case 17 had had a number of drugs, including barbiturates and sulphonamides, before his illness. The latter case has been reported by Cameron, Baron, and Priestley (1966).

\section{MISCELLANEOUS}

There remain a group of patients with ulcerative colitis who developed skin lesions which cannot be classified.

Case 16 developed what appeared to be an allergic vasculitis and one patient developed a subacute cellulitis of the buttocks (case 18).

A boy of 13 developed ulcerative colitis with multisystem involvement, including purpura, suggesting a possibly widespread disturbance of the immune mechanism.

CASE 19 This patient had ulcerative colitis with involvement of the whole colon on radiographs. He developed spontaneous bruising and purpura of the legs with a normal platelet count and bleeding and clotting times. 
However, he had evidence of a widespread autoimmune disturbance with raised gamma globulin, hepatosplenomegaly, jaundice, steatorrhoea, and arthritis. Antinuclear factor was present but no LE cells were found. The prothrombin time was increased. For a time he was controlled by ACTH, 30 units every third day, but after a severe rectal hemorrhage this was stopped. The diarrhoea, arthritis, and purpura recurred. A proctocolectomy was performed five years after the onset of the disease and afterwards he improved considerably.

Finally case 20 gave a history of chronic, slowly healing pustules on the shins for two years. When seen, however, his skin was normal except for scars on the lower legs.

\section{DISCUSSION}

Previous reports (Table I) show a wide variation in the total incidence of skin complications of colitis. The figures are influenced by a number of different factors. Many surveys are wholly or partly retrospective and depend upon the consistency of reporting cutaneous complications in the hospital records. The lowest incidence $(2 \%)$ was found in a series of 2,000 patients seen at the Mayo Clinic (Sloan, Bargen, and Gage, 1950). The highest figure (Lindenburg, 1958) includes mucosal lesions in a $35 \%$ incidence of cutaneous complications. Stomatitis is in fact fairly common among patients with intestinal disease. We have not, however, included it in this series because we are not satisfied that we have an accurate record of its incidence among our patients.

Some authors include in their lists toxic erythema, erythema multiforme, urticaria, purpura, herpes zoster, erysipelas, and pellagra (Hightower, Broders, Haines, McKenney, and Sommer, 1958; Kelley, 1963; Edwards and Truelove, 1964). As the colitis

TABLE I

\begin{tabular}{|c|c|c|c|c|c|c|c|c|}
\hline Year & Source & $\begin{array}{l}\quad \text { INCIDENCE } \\
\text { No. of Cases of } \\
\text { Ulcerative } \\
\text { Colitis }\end{array}$ & $\begin{array}{l}\text { OF SKIN } \\
\text { Erythema } \\
\text { Nodosum } \\
(\%)\end{array}$ & $\begin{array}{l}\text { LESIONS WITH } \\
\text { Pyoderma } \\
\text { Gangrenosum } \\
(\%)\end{array}$ & $\begin{array}{l}\text { ULCERATIVE } \\
\text { Pustular } \\
\text { Lesion } \\
(\%)\end{array}$ & $\begin{array}{l}\text { COLITIS } \\
\text { Unspecified } \\
\text { Erythema } \\
(\%)\end{array}$ & $\begin{array}{l}\text { Total } \\
(\%)\end{array}$ & Authors \\
\hline 1929 & Mayo Clinic & 603 & - & - & 一 & - & $2 \cdot 5$ & Bargen \\
\hline 1938 & Mayo Clinic & 871 & $1 \cdot 0$ & $0 \cdot 5$ & 一 & - & - & $\begin{array}{l}\text { Bargen, Jackman, } \\
\text { and Kerr }\end{array}$ \\
\hline 1946 & Chicago & 206 & - & - & $5 \cdot 0$ & $2 \cdot 0$ & $10 \cdot 0$ & Rickets and Palmer \\
\hline 1948 & Chicago & 100 & $9 \cdot 0$ & $4 \cdot 0$ & - & - & - & Kirsner et al \\
\hline 1949 & Boston & 180 & - & - & - & - & $9 \cdot 0$ & Warren and Somers \\
\hline 1950 & Mayo Clinic & 2,000 & $1 \cdot 0$ & $1 \cdot 5$ & - & $0 \cdot 1$ & $2 \cdot 0$ & $\begin{array}{l}\text { Sloan, Bargen, and } \\
\text { Gage }\end{array}$ \\
\hline 1950 & $\begin{array}{l}\text { Radcliffe Infirmary. } \\
\text { Oxford }\end{array}$ & 129 & $3 \cdot 0$ & $1 \cdot 0$ & $1 \cdot 0$ & $2 \cdot 0$ & $9 \cdot 0$ & $\begin{array}{l}\text { Rice-Oxley and } \\
\text { Truelove }\end{array}$ \\
\hline 1950 & Durham, Carolina & 112 & - & - & - & - & $3 \cdot 0$ & Bone et al \\
\hline 1951 & $\begin{array}{l}\text { Graduate Hospital, } \\
\text { Philadelphia }\end{array}$ & 189 & $6 \cdot 0$ & $12 \cdot 0$ & - & - & $21 \cdot 0^{2}$ & $\begin{array}{l}\text { Samitz and } \\
\text { Greenberg }\end{array}$ \\
\hline 1951 & $\begin{array}{l}\text { Montefiore Hospital, } \\
\text { New York }\end{array}$ & 147 & - & - & - & - & $11 \cdot 5$ & $\begin{array}{l}\text { Brown, Kasich, and } \\
\text { Weingarten }\end{array}$ \\
\hline 1956 & $\begin{array}{l}\text { Graduate Hospital, } \\
\text { Philadelphia }\end{array}$ & 125 & $5 \cdot 0$ & $2 \cdot 0$ & $6 \cdot 0$ & - & $11 \cdot 0$ & Bockus et al \\
\hline 1957 & $\begin{array}{l}\text { Beth Israel Hospital, } \\
\text { Boston }\end{array}$ & 702 & $2 \cdot 0$ & $0 \cdot 5$ & $2 \cdot 0$ & - & - & $\begin{array}{l}\text { Banks, Korelitz, and } \\
\text { Zetzel }\end{array}$ \\
\hline 1958 & $\begin{array}{l}\text { Scott \& White Clinic, } \\
\text { Texas }\end{array}$ & 220 & - & - & - & - & $6 \cdot 0$ & Hightower et al \\
\hline 1958 & Norway & 106 & $3 \cdot 0$ & $2 \cdot 0$ & - & - & $14 \cdot 0$ & Alm and Ihre \\
\hline 1958 & Denmark & 161 & - & - & - & - & $35 \cdot 0^{1}$ & Lindenburg \\
\hline 1958 & Detroit & 75 & $2 \cdot 5$ & - & - & - & - & Baltz \\
\hline 1958 & Philadelphia & 317 & - & - & - & - & $2 \cdot 2$ & Bacon \\
\hline 1959 & Lahey Clinic & 555 & $3 \cdot 0$ & 一 & - & - & - & Fernandez-Herlihy \\
\hline 1959 & Leeds & 108 & - & - & - & - & $11 \cdot 0$ & $\begin{array}{l}\text { Wright and } \\
\text { Watkinson }\end{array}$ \\
\hline 1963 & Rochester, New York & 142 & $9 \cdot 0$ & - & $6 \cdot 0$ & $7 \cdot 0$ & $24 \cdot 0$ & Kelley \\
\hline 1963 & $\begin{array}{l}\text { Harper Hospital, } \\
\text { Detroit }\end{array}$ & 110 & $2 \cdot 0$ & $2 \cdot 0$ & - & - & 一 & Barron and Ruel \\
\hline 1963 & $\begin{array}{l}\text { Radcliffe Infirmary, } \\
\text { Oxford }\end{array}$ & 624 & $2 \cdot 0$ & $1 \cdot 0$ & 一 & - & $10 \cdot 0^{3}$ & $\begin{array}{l}\text { Edwards and } \\
\text { Truelove }\end{array}$ \\
\hline 1963 & Stockholm & 202 & $2 \cdot 5$ & $1 \cdot 5$ & - & - & $11 \cdot 0$ & Ihre \\
\hline 1964 & $\begin{array}{l}\text { Mount Sinai Hospital, } \\
\text { New York }\end{array}$ & 238 & $5 \cdot 0$ & - & $4 \cdot 0$ & - & - & $\begin{array}{l}\text { Korelitz and } \\
\text { Lindner }\end{array}$ \\
\hline 1966 & Chicago & 220 & 0.5 & $1 \cdot 5$ & - & - & - & $\begin{array}{l}\text { Sparberg, Fennessy, } \\
\text { and Kirsner }\end{array}$ \\
\hline \multicolumn{2}{|c|}{ Present series } & 415 & $2 \cdot 0$ & $2 \cdot 0$ & - & - & $4 \cdot 8$ & \\
\hline
\end{tabular}

${ }^{1}$ Including mucosal lesions.

${ }^{2}$ After exclusion of mucosal aphthae.

${ }^{3}$ After exclusion of lesions unrelated to or preceding colitis.

2 
may last most of an adult's life time the patient may develop various unrelated skin conditions and it would seem more informative to exclude those of doubtful relevance. Of 624 patients suffering from colitis Edwards and Truelove (1964) found 117 suffering from skin disease. In 13 cases, however, the cutaneous disease preceded the onset of the colitis and in another 24 cases there was no evidence to suggest a causal relationship. We found the incidence to be $4.8 \%$ of a series of 415 patients suffering from colitis but included only those skin conditions which occurred more frequently in cases of colitis than in the general population or which erupted during periods of activity of the colitis.

ERYTHEMA NODOSUM Erythema nodosum was the commonest condition found, the affected patients being all women. Its occurrence did not depend upon the extent of colonic involvement but the attacks coincided with the activity of the colitis as has been the experience of most observers (Rice-Oxley and Truelove, 1950; Kelley, 1963). There have been occasional reports of erythema nodosum preceding the colitis (Fernandez-Herlihy, 1959; Edwards and Truelove, 1964) but we did not see such a case. Ulceration of the nodules does not normally occur but has previously been reported in patients suffering from ulcerative colitis (Russell 1950; Kelley and Logan, 1956). In one of our patients several nodes in front of the shins broke down and ulcerated but healed rapidly after colectomy.

An association between erythema nodosum and arthropathy is well established (Foster and Brick 1954, Bywaters and Ansell, 1958; FernandezHerlihy, 1959; Jacobs, 1959) and seven of our eight patients complained of both conditions.

After control of the colitis by medical or surgical means there was no recurrence of the erythema nodosum, a finding which previous authors have also reported (Bargen, 1929; Samitz and Greenberg, 1951; Kelley and Logan, 1956).

PYODERMA GANGRENOSUM Pyoderma gangrenosum was originally given this name by Brunsting, Goeckerman, and O'Leary (1930) who reported five patients, four of whom had ulcerative colitis

TABLE II

HAEMATOLOGICAL AND SERUM PROTEIN VALUES AT THE TIME OF ONSET OF THE SKIN LESIONS IN THE PRESENT SERIES

\begin{tabular}{|c|c|c|c|c|c|c|c|c|c|}
\hline Case No. & Initials & Sex & $\begin{array}{l}\text { Age } \\
\text { at Onset }\end{array}$ & $\begin{array}{l}\text { Skin } \\
\text { Lesions }\end{array}$ & Type of Skin Lesion & Site & $H b(g \%)$ & $W B C$ & $E S R$ \\
\hline 1 & A.T. & $\mathrm{F}$ & 26 & 30 & $\begin{array}{l}\text { Erythema nodosum, } \\
\text { ulcerating }\end{array}$ & Shins & $11 \cdot 8$ & - & 100 \\
\hline 2 & A.G. & $\mathrm{F}$ & 36 & $\begin{array}{l}52 \\
57\end{array}$ & $\begin{array}{l}\text { Erythema nodosum, } \\
\text { papulonecrotic lesions }\end{array}$ & $\begin{array}{l}\text { Shins, } \\
\text { neck and chest }\end{array}$ & $\begin{array}{r}8 \cdot 0 \\
11 \cdot 0\end{array}$ & 5,000 & 95 \\
\hline 3 & D.P. & $\mathbf{F}$ & 18 & 21 & $\begin{array}{l}\text { Erythema nodosum, } \\
\text { papulonecrotic lesions, } \\
\text { chronic ulcer, } \\
\text { Ulcerated plaques }\end{array}$ & $\begin{array}{l}\text { Shins, } \\
\text { legs and ankles, } \\
\text { face } \\
\text { Shins }\end{array}$ & $9 \cdot 8$ & 9,000 & 10 \\
\hline 4 & E.B. & $\mathrm{F}$ & 21 & 21 & Erythema nodosum & $\begin{array}{l}\text { Shins, buttocks, } \\
\text { thighs } \\
\text { Thighs }\end{array}$ & $11 \cdot 8$ & - & 18 \\
\hline 5 & Y.D. & $\mathbf{F}$ & 22 & $\begin{array}{l}27 \\
23 \\
24 \frac{1}{2}\end{array}$ & $\begin{array}{l}\text { Necrotic ulcer } \\
\text { Acne (steroid) } \\
\text { ecthyematous ulcers } \\
\text { Erythema nodosum, } \\
\text { ulcerated plaques }\end{array}$ & $\begin{array}{l}\text { Thighs } \\
\text { Face } \\
\text { buttocks, thighs, } \\
\text { Shins, } \\
\text { shins }\end{array}$ & $10 \cdot 6$ & 7,000 & 31 \\
\hline 6 & M.L. & $\mathbf{F}$ & 32 & $32 !$ & Erythema nodosum & Shins & $10 \cdot 4$ & 10,800 & 66 \\
\hline 7 & C.S. & $\mathrm{F}$ & 12 & 26 & Erythema nodosum & $\begin{array}{l}\text { Shins, thighs, arms, } \\
\text { hands }\end{array}$ & $9 \cdot 0$ & 16,000 & 48 \\
\hline 8 & D.M. & $\mathbf{F}$ & 22 & 27 & $\begin{array}{l}\text { Erythema nodosum, } \\
\text { purpura }\end{array}$ & Shins & & & \\
\hline 9 & M.K. & $\mathbf{F}$ & 65 & $68 \frac{1}{2}$ & Ulcerated plaques & Shins & $14 \cdot 2$ & 11,000 & - \\
\hline 10 & D.W. & $\mathbf{F}$ & 21 & 43 & $\begin{array}{l}\text { Papulonecrotic lesions, } \\
\text { necrotic ulcer }\end{array}$ & $\begin{array}{l}\text { Face, chest, ankles } \\
\text { Foot }\end{array}$ & $12 \cdot 4$ & 7,000 & - \\
\hline 11 & C.M. & $\mathrm{F}$ & 12 & 15 & Ulcers & Legs & $11 \cdot 5$ & 25,000 & 43 \\
\hline $\begin{array}{l}12 \\
13\end{array}$ & G.R. & $\mathbf{F}$ & 51 & 62 & Ulcers & Inguinal & $8 \cdot 1$ & & - \\
\hline 13 & M.D. & $\mathbf{F}$ & 18 & $\begin{array}{l}28 \\
32\end{array}$ & $\begin{array}{l}\text { Erythema multiforme } \\
\text { Papulonecrotic lesions, } \\
\text { ulcers }\end{array}$ & $\begin{array}{l}\text { Legs, mouth, vagina } \\
\text { Scalp, chest } \\
\text { Hand, ankles }\end{array}$ & $\begin{array}{l}8 \cdot 8 \\
5 \cdot 4\end{array}$ & $\overline{3}, 000$ & 50 \\
\hline 14 & D.S. & $\mathbf{F}$ & 20 & 31 & Ulcers & Legs & & & \\
\hline 15 & M.A. & $\mathbf{M}$ & 19 & 27 & Papulonecrotic lesions & Trunk, scalp, legs & $12 \cdot 6$ & - & 21 \\
\hline 16 & S.W. & $\mathbf{M}$ & 43 & 49 & Vasculitis & Legs & $10 \cdot 7$ & 14,000 & 28 \\
\hline $\begin{array}{l}17 \\
18\end{array}$ & $\begin{array}{l}\text { W.D. } \\
\text { H.C. }\end{array}$ & $\begin{array}{l}\mathbf{M} \\
\mathbf{M}\end{array}$ & $\begin{array}{l}40 \\
53\end{array}$ & $\begin{array}{l}40 \\
66\end{array}$ & $\begin{array}{l}\text { Erythema multiforme } \\
\text { Cellulitis }\end{array}$ & $\begin{array}{l}\text { Mouth, limbs, penis } \\
\text { Buttocks }\end{array}$ & $14 \cdot 1$ & 11,500 & 23 \\
\hline $\begin{array}{l}19 \\
20\end{array}$ & $\begin{array}{l}\text { C.G. } \\
\text { G.W. }\end{array}$ & $\begin{array}{l}\mathbf{M} \\
\mathbf{M}\end{array}$ & $\begin{array}{l}13 \\
42\end{array}$ & $\begin{array}{l}13 \\
47\end{array}$ & $\begin{array}{l}\text { Purpura } \\
\text { Pustules, chronic }\end{array}$ & Shins & $\begin{array}{l}10 \cdot 9 \\
10 \cdot 9\end{array}$ & 13,300 & 96 \\
\hline
\end{tabular}


and one a chronic empyema. In this condition crops of small discrete pustules appeared and within a few days the overlying skin broke down. The lesions either involuted or extended peripherally to coalesce and form larger ulcers with a necrotic undermined, dusky advancing edge. All the cases seen in our series had comparatively small localized areas of pyoderma. We feel, however, that these are essentially of the same nature as the large spreading superficial ulcers which may require skin grafting (Butler, 1950). They may be found in association with various debilitating diseases but 11 of 19 cases reported by Perry and Brunsting (1957) had ulcerative colitis. The earliest lesion has been described as an intraepidermal bulla (Percival 1957; Edwards and Truelove, 1964). Various bacteria have been isolated from the lesions but none consistently and the initial pustules are frequently sterile. The histopathology is not diagnostic (Lever, 1967) and lends no support to the theory of Rostenberg (1953) that ulceration is the result of a Schwartzman reaction. Hypogammaglobulinaemia has been reported (Marcussen, 1955) but parenteral replacement of gamma globulins failed to check the progress of the ulcers.

It is often considered that pyoderma gangrenosum is a complication of severe and active colitis but this is not invariably the case. Edwards and Truelove (1964) found that ulceration of the skin might persist for years even when symptoms of colitis were absent or slight. Sparberg, Fennessy, and Kirsner (1966) reviewed 220 patients with mild ulcerative colitis and found one case of pyoderma gangrenosum in 45 patients with proctitis only and two cases among 114 patients with sigmoidoscopic changes beyond the rectum but a normal barium enema. Margoles and Wenger (1961) describe the appearance of necrotic ulcers on the limbs six months after proctocolectomy and Cook and Lorincz (1962) saw pyoderma gangrenosum develop 10 years after total colectomy. The seven patients in our series showed no correlation between the severity

TABLE II-continued

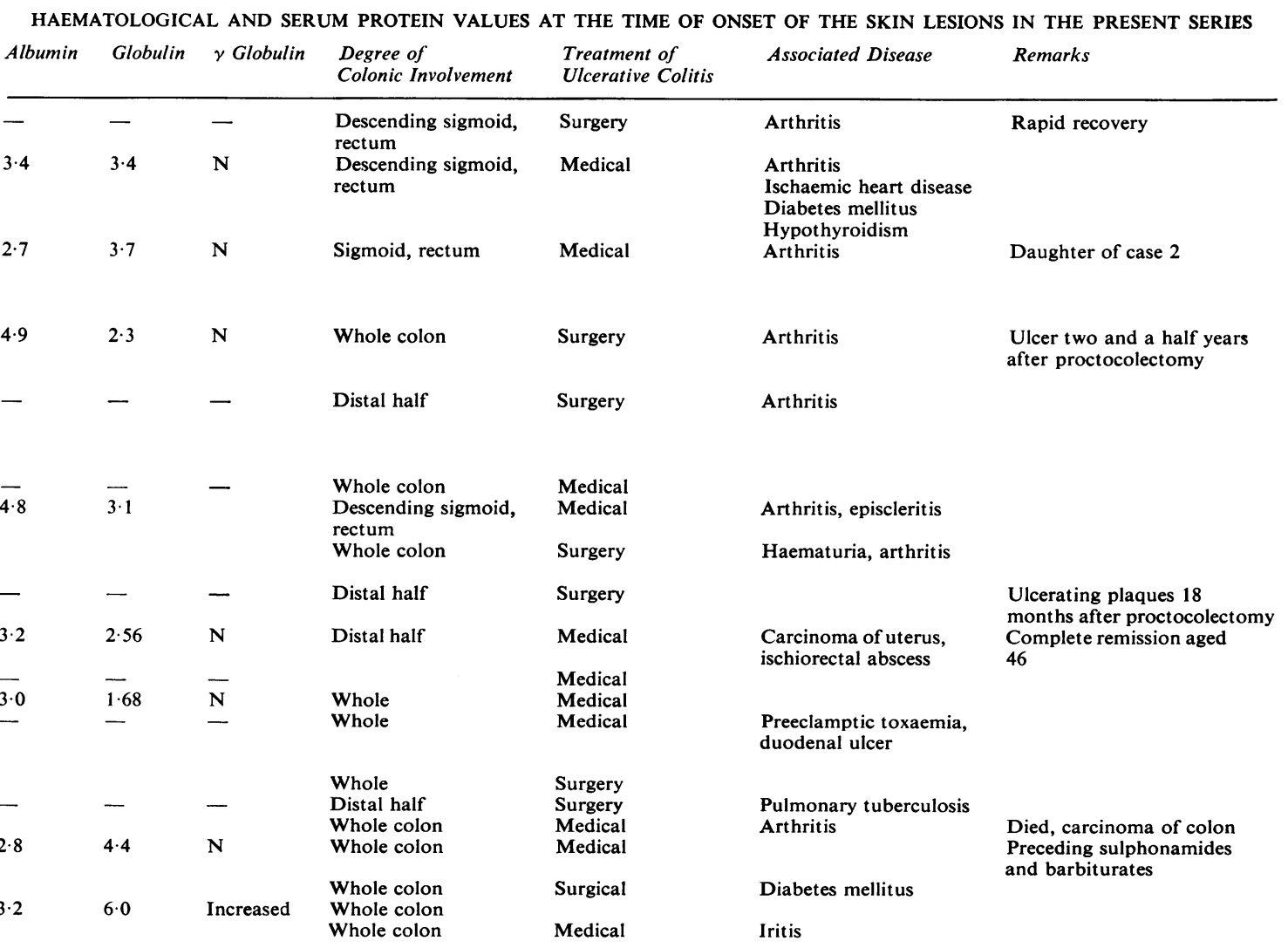


of the colitis and the presence of necrotic ulcers and one developed an ulcer two and a half years after removal of the colon and rectum.

PAPUlONECROTIC Lesions Papulonecrotic lesions occurring with ulcerative colitis have been described by Lagercrantz, Winberg, and Zetterström (1958), by Kelley (1963), by Edwards and Truelove (1964), and by others. There were seven such cases in our series, the ulcers being sterile and responding to oral steroids. We found little or no relationship between the appearance of these lesions and the extent and activity of the colitis.

ULCERATING ERYTHEMATOUS PLAQUES Ulcerating erythematous plaques (Figs. 3-5) were seen in three patients. They developed over the shins and broke down to form multiple small ulcers which did not coalesce. Although we have not seen any description in the literature of this particular lesion, Jankelson and McClure (1940) show a photograph of a very similar one. We have only seen one other patient who was similarly affected, a girl with Crohn's disease.

OTHER LESIONS Cameron et al (1966) reported four cases of erythema multiforme in association with ulcerative colitis, including case 17 of our series, and, after reviewing the literature, concluded that in all cases except one (Crawford and Luikart, 1949) the skin condition could have been due to a drug. In our case 13 the erythema multiforme occurred during toxaemia of pregnancy, an association which is well known.

Other skin diseases may occur spasmodically in association with ulcerative colitis but the association is most probably due to chance. However, Forman (1966) has reported 12 cases of pyodermite vegetante, eight of which had ulcerative colitis. In this disease multiple superficial vesicopustules occur and vegetations of the skin develop in the flexures. The oral and ocular mucosae are also involved. The patients generally remain well and the histology and clinical course of the disease distinguish it from pemphigus vegetans.

A characteristic of all the skin lesions associated with ulcerative colitis is a tendency to necrose and form chronic ulcers of varying morphology. This even occurs as a complication of erythema nodosum which, as a rule, never ulcerates.

It may be suggested that the various skin lesions in ulcerative colitis are all manifestations of the same basic pathological process with the end result of erythema or various types of necrosis or ulceration determined by the state of the skin of the patient at that particular stage of the disease.
However, the histological appearances of the lesions would not support this. Erythema nodosum is primarily a vasculitis with swelling of the endothelial cells and a local perivascular inflammatory infiltrate, whereas in pyoderma gangrenosum the chronic inflammatory infiltrate is widespread and the vessels are only slightly involved. Also the behaviour of erythema nodosum, with its relationship to exacerbations of the colitis and its disappearance after control of the bowel disease, distinguishes it from the chronic ulcerative lesions of whatever pattern which bear no close relationship to the severity of the colitis.

The histopathology and genesis of the skin lesions in ulcerative colitis require further study.

\section{SUMMARY}

In a series of 415 cases of ulcerative colitis, 20 patients (14 women) had skin disease thought to be associated with the underlying bowel disease. Seven patients had more than one morphological type of skin lesion.

Eight women had erythema nodosum of which the onset was associated with exacerbations of the colitis. Seven had a seronegative arthropathy and in one case the nodes ulcerated.

Seven women had chronic ulcers (pyoderma gangrenosum). There was no correlation with the extent or severity of the colitis and in one case the ulcer appeared two and a half years after proctolectomy.

Five patients had papulonecrotic lesions which bore no relationship to the severity of the underlying colitis.

Three women developed erythematous plaques on the shins which ulcerated in several places, but these small ulcers did not coalesce. This lesion is thought to occur only in ulcerative colitis.

Cases were also seen with erythema multiforme, allergic vasculitis, purpura, and subacute cellulitis of the buttocks.

We are grateful to Dr F. Avery Jones and Dr T. D. Kellock for allowing us to study their patients.

\section{REFERENCES}

Alm, T., and Ihre, B. (1958). Colit is ulcerosa. Nord. Med., 59, 572-575. Bacon, H. E. (1958). Ulcerative Colitis. Lippincott, Philadelphia.

Baltz, J. I. (1958). Observations on the course of non-specific ulcerative colitis. Postgrad. Med., 24, 17-25.

Banks, B. M., Korelitz, B. I., and Zetzel, L. (1957). The course of non-specific ulcerative colitis: review of twenty years' experience and late results. Gastroenterology, 32, 983-1012.

Bargen, J. A. (1929). Complications and sequelae of chronic ulcerative colitis. Ann. intern. Med., 3, 335-352.

, Jackman, R. J., and Kerr, J. G. (1938). Studies on the life histories of patients with chronic ulcerative colitis (thrombo- 
ulcerative colitis) with some suggestions for treatment. Ann. intern. Med., 12, 339-352.

Barron, R. A., and Ruel, R. E. (1963). Serious complications of ulcerative colitis. Review of cases, 1950-61. Harper Hosp. Bull. 21, 70-73.

Bockus, H. L., Roth, J. L. A., Buchman, E., Kalser, M., Staub, W. R., Finkelstein, A., and Valdes-Dapena, A. (1956). Life history of non-specific ulcerative colitis. Relation of progress to anatomical and clinical varieties. Gastroenterologia (Basel), 86, 549-581.

Bone, F. C., Ruffin, J. M., Baylin, G. J., and Cassel, C. (1950). The clinical course of idiopathic ulcerative colitis. Prognostic implications. Sth. med.J. (Bgham, Ala.), 43, 817-823.

Brown, M. L., Kasich, A. M., and Weingarten, B. (1951). Complications of chronic ulcerative colitis. Amer. J. dig. Dis., 18, 52-54.

Brunsting, L. A., Goeckerman, W. H., and O'Leary, P. A. (1930). Pyoderma (echthyma) gangrenosum. Arch. Derm. Syph. (Chic.), 22, 655-680.

Butler, E. C. B. (1950). Spreading ulceration of the skin associated with idiopathic ulcerative colitis. Amer. J. Surg., 79, 96-100.

Bywaters, E. G. L., and Ansell, B. M. (1958). Arthritis associated with ulcerative colitis. A clinical and pathological study. Ann. Rheum. Dis., 17, 169-183.

Cameron, A. J., Baron, J. H., and Priestley, B. L. (1966). Erythema multiforme, drugs and ulcerative colitis. Brit. med. J., 2, 1174-1178.

Cook, T. J., and Lorincz, A. L. (1962). Pyoderma gangrenosum appearing ten years after colectomy and apparent cure of chronic ulcerative colitis. Arch. Derm., 86, 105-106.

Crawford, G. M., and Luikart, R. H., II (1949). Severe erythema multiforme with intestinal involvement. J. Amer. med. Ass., 140, 780-781.

Edwards, F. C., and Truelove, S. C. (1964). The course and prognosis of ulcerative colitis. Part III. Complications. Gut, 5, 1-15.

Fernandez-Herlihy, L. (1959). The articular manifestations of chronic ulcerative colitis. An analysis of 555 cases. New Engl. J. Med. 261, 259-263

Forman, L. (1966). The skin and the colon. Trans. St. John's Hosp. derm. Soc. (Lond.), 52, 139-162.

Foster, J. J., and Brick, I. B. (1954), Erythema nodosum in ulcerative colitis. Gastroenterology, 27, 417-425.

Hightower, N. C., Jr, Broders, A. C., Haines, R. D., McKenney, J. F., and Sommer, A. W. (1958). Chronic ulcerative colitis. II, Complications. Amer. J. dig. Dis., 3, 861-876.

Ihre, B. J. E. (1963). Ulcerative colitis from a surgical point of view. Acta chir. scand., 125, 453-462.

Jacobs, W. H. (1959). Erythema nodosum in inflammatory diseases of the bowel. Gastroenterology, 37, 286-294.

Jankelson, I. R., and McClure, C. W. (1940). Skin lesions during the course of ulcerative colitis. Acta derm. venereol. (Stockh.), 21, 255-267.
Kelley, M. L., Jr (1963). Chronic ulcerative colitis at a Medical Center in Western New York State. Complications and course. N.Y. State J. Med., 63, 2061-2075.

-, and Logan, V. W. (1956). Erythema nodosum in association with chronic ulcerative colitis. Gastroenterology, 31, 285-295.

Kirsner, J. B., Palmer, W. L., Maimon, S. N., and Ricketts, W. E. (1948). Clinical course of chronic non-specific ulcerative colitis. J. Amer. med. Ass., 137, 922-928.

Korelitz, B. I., and Lindner, A. E. (1964). The influence of corticotrophin and adrenal steroids on the course of ulcerative colitis: a comparison with the pre-steroid era. Gastroenterology, 46, 671-679.

Lagercrantz, R., Winberg, J., and Zetterström, R. (1958). Extracolonic manifestations in chronic ulcerative colitis. Acta paediat. (Uppsala), 47, 675-687.

Lever, W. F. (1967). Histopathology of the Skin, 4th ed. Pitman, London.

Lindenberg, J. (1958). Ulcerative colitis. Treatment and prognosis studied on the basis of 161 cases. Acta chir. scand., suppl., 236, 56-90.

Marcussen, P. V. (1955). Hypogammaglobulinemia in pyoderma gangrenosum. J. invest. Derm., 24, 275-280.

Margoles, J. S., and Wenger, J. (1961). Stomal ulceration associated with pyoderma gangrenosum and chronic ulcerative colitis. Report of two cases. Gastroenterology, 41, 594-598.

Percival, G. H. (1957). Pyoderma gangrenosum. The histology of the primary lesion. Brit.J. Derm., 69, 130-136.

Perry, H. O., and Brunsting, L. A. (1957), Pyoderma gangrenosum. A clinical study of nineteen cases. Arch. Derm., 75, 380-386.

Rice-Oxley, J. M., and Truelove, S. (1950). Complications of ulcerative colitis. Lancet, 1, 607-611.

Ricketts, W. E., and Palmer, W. L. (1946). Complications of chronic non-specific ulcerative colitis. Gastroenterology, 7, 55-66.

Rostenberg, A., Jr (1953). The Shwartzman phenomenon: a review with a consideration of some, possible dermatological manifestations. Brit. J. Derm., 65, 389-405.

Russell, B. (1950). Phagedenic and gangrenous ulceration of the skin complicating ulcerative colitis (phagedena geometricum). Brit. J. Derm., 62, 114-124.

Samitz, M. H., and Greenberg, M. S. (1951). Skin lesions in association with ulcerative colitis. Gastroenterology, 19, 476-479.

Sloan, W. P., Jr Bargen, J. A., and Gage, R. P. (1950). Life histories of patients with chronic ulcerative colitis: a review of 2000 cases. Ibid., 16, 25-38.

Sparberg, M., Fennessy, J., and Kirsner, J. B. (1966). Ulcerative proctitis and mild ulcerative colitis. A study of 220 patients. Medicine (Baltimore), 45, 391-412.

Warren, S., and Sommers, S. C. (1949). Pathogenesis of ulcerative colitis. Amer. J. Path., 25, 657-679.

Wright, V., and Watkinson, G. (1959). The arthritis of ulcerative colitis. Medicine (Baltimore), 38, 243-262. 